Volume 2 Nomor 2, Juli-Desember 2018: hlm. 85-92. Magister Ilmu Hukum, Fakultas Hukum, Universitas Lampung, Bandar Lampung, Lampung, Indonesia. E-ISSN: 2598-3105 P-ISSN: 2723-2581 http://jurnal.fh.unila.ac.id/index.php/cepalo

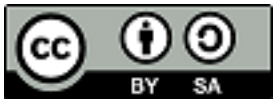

\title{
MODEL PENGUASAAN TANAH OLEH MASYARAKAT DESA MARGOSARI DAN PENYELESAIAANNYA PADA KAWASANHUTAN LINDUNG REGISTER 22 WAY WAYA KABUPATEN PRINGSEWU
}

\section{(THE MODEL OF LAND TENURE BY MARGOSARI VILLAGE COMMUNITY AND ITS SETTLEMENT IN THE 22 WAY WAYA PROTECTED FOREST AREA, PRINGSEWU REGENCY)}

\author{
Kartiko Harnadi \\ Pemerintah Daerah Provinsi Lampung \\ Tiko_marley@yahoo.co.id
}

\begin{abstract}
Abstrak
Kawasan Hutan Lindung Register 22 Way Waya Kabupaten Pringsewu merupakan salah satu kawasan yang rentan terjadi konflik. Konflik tersebut terindikasi dari masyarakat desa Margosari yang menguasai dan memanfaatkan tanah di dalam kawasan hutan. Permasalahan yang dapat dibahas adalah bagaimana model penguasaan tanah oleh masyarakat dan bagaimana model penyelesaiaan status hukum penguasaan tanah di Desa Margosari Kabupaten Pringsewu. Metode penelitian yang digunakan adalah yuridis empiris. Penulis menemukan jawaban bahwa model pemanfaatan tanahnya adalah untuk berladang, usaha pertambangan, dan pemukiman. Tanah di desa Margosari yang berada di luar dan di dalam kawasan hutan belum ada yang bersertifikat. Sebagian besar bukti kepemilikannya adalah surat keterangan tanah, dan/atau surat peralihan di bawah tangan. Model penyelesaian status hukum tanah di dalam kawasan hutan yang dikuasai masyarakat Desa Margosari adalah melalui: 1) perhutanan sosial, atau 2) perubahan batas kawasan hutan.
\end{abstract}

Kata Kunci: Model Penyelesaian, Tanah, Hutan Lindung dan Desa.

\section{Abstract}

Protected Forest Register 22 Way Waya Pringsewu Regency is one area that is prone to conflict. The conflict is indicated from the people of Margosari village who control and use land in the forest area. The problem that can be discussed is how to model land tenure by the community and how to resolve the legal status of land tenure in Margosari Village, Pringsewu Regency. The research method used is empirical juridical.

The author finds the answer that the model of land use is for farming, mining, and settlement. Land in Margosari village that is outside and inside the forest area is not yet certified. Most proof of ownership is a land certificate, and / or transfer letter under the hand. The model for resolving the legal status of land in a forest area controlled by the Margosari village community is through: 1) social forestry, or 2) changes in the forest area boundary.

Keywords: Settlement Model, Land, Protection Forest and Village.

Cara Mengutip (How to Cite): Kartiko Harnadi, "Model Penguasaan Tanah oleh Masyarakat Desa Margosari dan Penyelesaiaannya pada Kawasan Hutan Lindung Register 22 Way Waya Kabupaten Pringsewu”, Jurnal Cepalo, 2 (2), (2018): 85-92.

DOI: https://doi.org/10.25041/cepalo.v2no2.1765 


\section{A. Pendahuluan}

Tanah sebagai sumber daya alam yang merupakan karunia Tuhan Yang Maha Esa kepada Bangsa Indonesia oleh sebab itu sudah sewajarnya apabila kita mengelola tanah dengan sebaikbaiknya agar pemanfaatannya dapat memberikan sebesar-besarnya kemakmuran rakyat sebagaimana diamanatkan dalam Pasal 33 ayat 3 Undang-Undang Dasar 1945. ${ }^{1}$ Berdasarkan fungsinya hutan digolongkan menjadi tiga jenis, yaitu Hutan Konservasi, Hutan Lindung, dan Hutan Produksi. Hutan Lindung adalah kawasan hutan yang mempunyai fungsi pokok sebagai perlindungan, sistem penyangga kehidupan untuk mengatur tata air, mencegah banjir, mengendalikan erosi, mencegah instrusi air laut dn memelihara kesuburan tanah. ${ }^{2}$ Kawasan Hutan Lindung Register 22 Way Waya merupakan salah satu kawasan yang rentan terjadi konflik kehutanan. Wilayah Register 22 Way Waya yang berada di Kabupaten Pringsewu seluas 4.777 hektar. Pada saat ini sebagian wilayah kawasan hutan telah dikuasai dan dimanfaatkan oleh penduduk sekitar. Berdasarkan Berita Acara Tata Batas Kawasan Hutan Lindung Register 22 Way Waya yang telah disahkan pada Tahun 2014 oleh Pejabat yang berwenang, wilayah Desa Margosari memang bersinggungan dengan kawasan hutan tersebut. Berdasarkan hasil Plotting dan Digitasi koordinat pada Berita Acara Tata Batas Kawasan Hutan Lindung Register 22 Way Waya, Peta Tata Ruang/Wilayah Kabupaten Pringsewu Tahun 2012, dan Peta Citra daerah sekitar Kawasan Hutan Lindung Register 22 Way Waya dan desa Margosari diperoleh data sebagai berikut:

1. Wilayah Desa Margosari yang berada di dalam kawasan hutan seluas \pm 77 Ha. Masyarakat Desa Margosari memanfaatkan kawasan tersebut untuk pemukiman dan perkebunan;

2. Wilayah Desa Margosari yang berada di luar kawasan hutan seluas \pm 90 Ha. Pada saat ini banyak dimanfaatkan untuk pemukiman dan perkebunan;

3. Wilayah Desa Margosari yang berada di luar dan di dalam kawasan hutan, yaitu seluas \pm 10 Ha. Lahan tersebut tidak diusahakan karena berupa sungai, jalan, dan parit.

Kegiatan pemanfaatan lahan hutan oleh Masyarakat Desa Margosari Kabupaten Pringsewu mengindikasikan sebagai perambahan hutan. Dalam konteks hukum agraria dan kehutanan hal tersebut merupakan suatu masalah. Sampai saat ini jaminan atas penguasaan dan pemanfaatan tanah yang telah mereka lakukan belum ada kejelasan dan kepastian. Padahal penguasaan dan pemanfaatan tanah sudah berlangsung dalam waktu yang lama.

Permasalahan yang akan dibahas dalam tulisan ini adalah bagaimana model penguasaan tanah oleh masyarakat dan bagaimana model penyelesaiaan status hukum penguasaan tanah di Desa Margosari Kabupaten Pringsewu. Metode penelitian yang digunakan adalah yuridis empiris. Alasan penggunaan metode ini antara lain Pertama, analisis digunakan terhadap teori negara hukum kesejahteraan, teori keberlanjutan ekologi, teori kewenangan, dan teori kepastian hukum, peraturan perundang-undangan, dan data lapangan di Desa Margosari. Kedua, data dan informasi yang dianalisis memiliki sifat dasar yang berbeda antara yang satu dengan lainnya. Data spasial pada kantor Pertanahan Kabupaten Pringsewu dan Dinas Kehutanan Provinsi Lampung, dan informasi terkait kepemilikan dan penguasaan masyarakat Desa Margosari memiliki sifat yang berbeda namun merupakan suatu kesatuan yang integral.

\section{B. Pembahasan}

Pada saat ini, permasalahan pertanahan pada kawasan hutan sangat kompleks dan rentan terjadi. Konflik agraria pada kawasan hutan berdampak secara ekonomi, sosial, budaya, dan keamanan bagi masyarakat khususnya. Latar belakang masyarakat menguasai tanah yang masuk ke dalam kawasan hutan sangat beragam. Penunjukan kawasan hutan oleh pemerintah secara sepihak di masa lalu menjadi salah satu faktor pemicu konflik yang terjadi pada areal sekitar kawasan hutan. ${ }^{3}$

\footnotetext{
${ }^{1}$ Arie S. Hutagalung, Tebaran Pemikiran Seputar Masalah Hukum Tanah, Jakarta: Lembaga Pemberdayaan Hukum Indonesia, (2005), hlm. 19.

${ }^{2}$ Inrayanto, Oktinaldi, Model Pengolahan Hutan Lindung Sebagai Lahan Pertanian Masyarakat (Studi Kasus di Kenagarian Air Dingin Kecamatan Lembah Gumanti Kabupaten Solok), Skripsi, Jurusan Antropologi, Fakultas Ilmu Sosial dan politik, Sumatera Barat: Universitas Andalas, (2012), hlm 32.

${ }^{3}$ Fx. Sumarja, Muhammad Akib, "Forest Resources Access Moro-Moro Farmer at Register 45 Lampung", Fiat
} 
Selain faktor tersebut, terdapat faktor-faktor lain yang mendorong masyarakat menguasai dan memanfaatkan tanah yang berada di sekitar kawasan hutan. Dalam penelitian ini, faktor penyebab lainnya adalah masyarakat Desa Margosari telah lama bertempat tinggal dan memanfaatkan hasil hutan tanpa pernah ada permasalahan. Masyarakat berpendapat tanah itu milik mereka dan merupakan hak mereka untuk mempergunakan dan memanfaatkannya. Mereka juga beranggapan bahwa dengan adanya Berita Acara Tata Batas Tahun 2014 maka tanah yang telah mereka manfaatkan selama ini tidak masuk dalam Berita Acara Tata Batas dan keluar dari kawasan hutan Lindung Register 22 Way Waya.

\section{Model Penguasaan Tanah Oleh Masyarakat Desa Margosari Kabupaten Pringsewu a. Di Luar Kawasan Hutan}

Pemanfaatan masyarakat Desa Margosari terhadap tanah yang berada di luar kawasan hutan dipergunakan untuk berkebun, usaha pertambangan skala kecil, dan tempat tinggal. Model penguasaan tanah oleh masyarakat Desa Margosari yaitu penguasaan tanah terus menerus dalam waktu 20 tahun. Namun berdasarkan hasil wawancara dengan Kepala Desa Margosari dan data yang terdapat di Kantor Pertanahan Kabupaten Pringsewu ternyata tanah Desa Margosari yang berada di luar dan di dalam kawasan hutan belum ada yang bersertifikat.

Masyarakat Desa Margosari selama ini mendasarkan penguasaan tanah dengan Surat Sporadik dan Surat Kepemilikan Atas Tanah. Perangkat Desa Margosari berani untuk mengeluarkan surat-surat sebagaimana tersebut di atas dikarenakan mereka berpedoman pada Berita Acara Tata Batas Kawasan Hutan Lindung Register 22 Way Waya Tahun 2014. Mereka meyakini tanah mereka itu tidak berada di dalam kawasan hutan.

\section{b. Di Dalam Kawasan Hutan}

Secara alami Hutan Lindung Register 22 Way Waya adalah habitat (home base) masyarakat Desa Margosari. Hal ini terlihat dari bagaimana masyarakat Desa Margosari sangat bergantung pada keberadaan hutan lindung tersebut untuk mengambil hasil sumber daya alam, berladang, dan bermukim. Walaupun telah dikeluarkan penetapan kawasan hutan oleh pemerintah, Masyarakat Desa Margosari yang telah menguasai tanahnya lebih dari 20 tahun secara berturutturut tidak pernah merasa kehilangan akses terhadap sumber daya hutan tersebut.

Bukti penguasaan masyarakat Desa Margosari atas tanah yang masuk dalam kawasan hutan sangat beragam. Sebagian masyarakat memiliki surat jual beli di bawah tangan, ada juga masyarakat yang memiliki Surat Keterangan Tanah, Sporadik dan Berita Acara Tua-Tua Kampung. Namun tidak sedikit juga masyarakat Desa Margosari yang tidak memiliki bukti atau surat kepemilikan/penguasaan atas tanah tersebut. Berdasarkan data yang terdapat pada Kantor Pertanahan Kabupaten Pringsewu dan hasil wawancara dengan Kepala Desa Margosari, tanah Desa Margosari yang berada di dalam kawasan hutan belum ada yang bersertifikat. Sehingga penguasaan tanahnya didasarkan pada penguasaan fisik secara berturut-turut dalam waktu yang lama.

\section{Model Penyelesaian Status Hukum Tanah Di Sekitar Kawasan Hutan}

\section{a. Di Luar Kawasan Hutan}

Model penyelesaian status hukum tanah yang berada di luar kawasan hutan, adalah melalui pendaftaran tanah pertama kali baik secara sporadis maupun sistematis. Hal ini dapat dilakukan sebagai solusi dalam konteks hukum agraria, yang pelaksanaannya diatur dalam Peraturan Pemerintah No. 24 Tahun 1997 tentang Pendaftaran Tanah.

\section{b. Di Dalam Kawasan Hutan Lindung}

Model penyelesaiaan status hukum tanah yang berada di dalam kawasan hutan telah diatur melalui Peraturan Presiden No. 88 Tahun 2017 Tentang Penyelesaian Penguasaan Tanah Dalam 
Kawasan Hutan. Politik hukum dikeluarkannya Peraturan Presiden ini adalah keinginan pemerintah memberikan kepastian hukum untuk meningkatkan kesejahteraan masyarakat yang telah menguasai tanah di dalam kawasan hutan dalam jangka waktu yang lama, besarnya komitmen pemerintah untuk dapat menyelesaikan sengketa atau konflik pertanahan terutama yang terkait dengan penguasaan tanah yang berada di dalam kawasan hutan. Prosedur penyelesaian penguasaan tanah dalam kawasan hutan sesuai dengan Pasal 20 Peraturan Presiden No. 88 Tahun 2017, adalah sebagai berikut: a) inventarisasi penguasaan tanah dalam kawasan hutan; b) verifikasi penguasaan tanah dan penyampaian rekomendasi; c) penetapan model penyelesaian penguasaan dan pemanfaatan tanah dalam kawasan hutan; d) penerbitan keputusan penyelesaian penguasaan dan pemanfaatan tanah dalam kawasan hutan; dan e) penerbitan sertifikat hak atas tanah. Berdasarkan Peraturan Presiden No. 88 Tahun 2017 tersebut, terdapat beberapa model penyelesaian status hukum tanah yang berada di dalam Kawasan Hutan, antara lain:

\section{1) Perubahan Batas Kawasan Hutan}

Perubahan batas kawasan hutan dilegalkan dengan diterbitkanya Surat Keputusan Perubahan Batas Kawasan Hutan setelah sebelumnya dilakukan penataan batas kawasan hutan. Berdasarkan hal ini, maka Berita Acara Tata Batas Kawasan Hutan Lindung Register 22 Way Waya yang telah dikeluarkan pada tahun 2014 seharusnya dapat ditindaklanjuti dengan suatu Surat Keputusan Perubahan Batas Kawasan Hutan yang dikeluarkan oleh Menteri Lingkungan Hidup dan Kehutanan. Surat Keputusan inilah yang dipergunakan sebagai dasar penerbitan sertifikat hak atas tanah Masyarakat Desa Margosari yang menguasai tanah di dalam Kawasan Hutan.

\section{2) Resettlement}

Resettlement adalah pemindahan penduduk dari kawasan hutan ke luar kawasan hutan. Model ini bisa dilakukan terhadap masyarakat Desa Margosari yang menguasai dan memanfaatkan tanah di dalam kawasan hutan. Masyarakat Desa Margosari dapat benar-benar mendapatkan kepastian hukum atas tanah baru/pengganti. Namun, model penyelesaiaan ini akan sulit dalam pelaksanaannya, karena masyarakat Desa Margosari sudah terlalu lama menggantungkan hidupnya di wilayah ini. Resettlement memerlukan tahapan yang cukup panjang, waktu yang lama, dan biaya yang mahal. Pelaksanaannya perlu keterbukaan pemerintah dan partisipasi aktif dari masyarakat, agar tidak terjadi permasakahan antara masyarakat dan pemerintah. Biaya yang ditimbulkan untuk melaksanakan resettlement ditanggung oleh pemerintah daerah, hal ini akan sangat memberatkan pemerintah daerah yang tidak memiliki sumber daya keuangan yang melimpah. Hal yang paling penting dalam pelaksanaan model ini, pemerintah tidak boleh melakukan pengusiran terhadap masyarakat Desa Margosari yang telah melakukan pendudukan. Pemerintah harus dapat menjamin kesejahteraan masyarakat Desa Margosari baik dari segi ekonomi, sosial, budaya, dan keamanan di tempat yang baru. Kementerian Lingkungan Hidup dan Kehutanan bersama dengan Pemerintah Daerah Provinsi Lampung dan Pemerintah Daerah Kabupaten Pringsewu harus dapat berperan aktif dalam melaksanakan model penyelesaian ini. Kerja sama yang baik antara kedua instansi pemerintah ini merupakan kunci keberhasilan resettlement.

\section{3) Tukar Menukar Kawasan Hutan}

Hal yang paling penting dalam melaksanakan model ini adalah tidak boleh mengurangi luas kawasan hutan tetap, dan tetap menjamin luas kawasan hutan paling sedikit 30\% dari luas daerah aliran sungai, pulau, dan/atau provinsi dengan sebaran yang proporsional sehingga dapat mempertahankan daya dukung kawasan hutan tetap layak kelola.

Biaya yang ditimbulkan dalam pelaksanaan model penyelesaian melalui tukar menukar kawasan hutan menjadi tanggung jawab pemerintah daerah. Hal ini akan sangat memberatkan keuangan pemerintah daerah. Model penyelesaian ini akan sulit dilakukan pada areal kawasan hutan yang telah dikuasai oleh masyarakat Desa Margosari. Hal ini terjadi karena Provinsi Lampung sendiri mengalami kesulitan untuk mencapai luas kawasan hutan sebesar 30\% dari 
luas daerah aliran sungai, pulau, dan/atau provinsi. Selain itu, model ini harus memperhitungkan keberlanjutan lingkungan hidup atau keberlanjutan aspek ekologi wilayah kawasan hutan yang berbatasan dengan wilayah Desa Margosari.

Jika melihat dari aspek kemasyarakatan, model ini akan lebih memberikan jaminan kesejahteraan bagi masyarakat, karena tanah yang mereka kuasai selama ini akan dilepaskan dari kawasan hutan dan dapat sepenuhnya menjadi hak mereka. Masyarakat juga tidak memerlukan adaptasi dengan lingkungan yang baru, mereka tinggal melanjutkan hidup mereka seperti sedia kala.

\section{4) Perhutanan Sosial}

Model ini dapat diterapkan pada wilayah Desa Margosari yang masuk ke dalam wilayah kawasan hutan. Dari segi kepastian hukum, program perhutanan sosial merupakan model penyelesaian yang sama-sama menguntungkan para pihak, atau dalam hal ini pemerintah dan masyarakat Desa Margosari. Pelaksanaannya tidak terlalu membutuhkan waktu yang lama, dan juga tidak terlalu menyulitkan. Negara tidak kehilangan kawasan hutannya, dan masyarakat juga masih dapat memanfaatkan tanah yang mereka kuasai/manfaatkan sejak lama. Dalam pelaksanaannya, harus benar-benar dipertimbangkan nilai manfaat kehutanan yang bisa didapatkan, karena bila tidak maka yang terjadi justru menimbulkan bencana lingkungan yang lebih besar. Pelaksanaan model penyelesaian ini memerlukan perencanaan, pelaksanaan, dan kontrol yang baik dari instansi yang berwenang. Penyelesaiaan melalui model ini cenderung lebih mudah terjadi penyalahgunaan wewenang dan atau pelanggaran hukum. Antisipasi terhadap pelanggaran ataupun penyalahgunaan wewenang dari pihak- pihak yang terlibat dalam pengambilan keputusan merupakan hal yang sangat penting dalam pelaksanaannya. Selain Peraturan Presiden No. 88 Tahun 2017 terdapat peraturan perundang-undangan lain yang mengatur tentang tanah yang termasuk dalam kawasan hutan lindung. Peraturan tersebut antara lain:

a) Undang-Undang Nomor 41 Tahun 1999 tentang Kehutanan;

b) Peraturan Pemerintah Republik Indonesia No. 104 Tahun 2015 Tentang Tata Cara Perubahan Peruntukan dan Fungsi Kawasan Hutan;

c) Keputusan Presiden Republik Indonesia No. 32 Tahun 1990 Tentang Pengelolaan Kawasan Lindung;

d) Keputusan Menteri Kehutanan Nomor 70/Kpts-II/2001 tentang Penetapan Kawasan Hutan, Perubahan Status dan Fungsi Kawasan Hutan;

e) Peraturan Menteri Agraria dan Tata Ruang/Kepala Badam Pertanahan Nasional Republik Indonesia No. 10 Tahun 2016 tentang Tata Cara Penetapan Hak Komunal Atas Tanah Masyarakat Hukum Adat dan Masyarakat yang Berada Dalam Kawasan Tertentu.

f) Terdapat perbedaan yang mendasar antara Peraturan Presiden No. 88 Tahun 2017 dengan peraturan perundang-undangan sebagaimana tersebut di atas. Peraturan Presiden No. 88 Tahun 2017 mengakomodir model penyelesaiaan status hukum tanah yang berada di dalam kawasan hutan lindung melalui perubahan batas kawasan hutan, tukar menukar kawasan hutan, dan resettlement. Dalam peraturan perundang-undangan yang lain model penyelesaiaan tersebut hanya dapat dilakukan pada hutan produksi.

\section{Langkah Konstruktif Terhadap Penyelesaian Status Hukum Tanah Sekitar Kawasan Hutan}

Karakteristik masyarakat Desa Margosari dan kompleksitas yang terjadi dalam pengelolaan kawasan hutan merupakan hal yang dapat menjadi pertimbangan dalam menentukan pilihan kebijakan yang paling tepat. Sehubungan dengan model penyelesaian status hukum tanah di dalam kawasan hutan yang telah disebutkan di atas, dapat disimpulkan bahwa model penyelesaiaan yang tepat untuk diterapkan pada Kawasan Hutan Lindung Register 22 Way Waya Kabupaten Pringsewu antara lain melalui:

a. Perhutanan Sosial

Model ini sebaiknya didahulukan dalam upaya menyelesaikan status tanah masyarakat Desa 
Margosari yang masuk dalam wilayah kawasan hutan, hal ini dikarenakan model penyelesaiaan ini bersifat non represif. Model ini dapat menghindari permasalahan sosiologis masyarakat Desa Margosari, hal ini menjadi penting karena masyarakat Desa Margosari sudah menguasai dan memanfaatkan tanah tersebut dalam waktu yang cukup lama, keterikatan masyarakat secara emosional dengan tanah miliknya yang berada di dalam kawasan hutan sudah terjalin begitu erat. Pelaksanaan model ini memerlukan perencanaan, pelaksanaan, dan kontrol yang baik dari instansi yang berwenang. Penyelesaiaan penguasaan tanah dalam kawasan hutan melalui Program Perhutanan Sosial cenderung lebih mudah terjadi penyalahgunaan wewenang atau pelanggaran hukum. Antisipasi terhadap pelanggaran atau penyalahgunaan wewenang dari pihak-pihak yang terlibat dalam pengambilan keputusan merupakan hal yang sangat penting dalam pelaksanaannya. Pemilihan model ini didasarkan pada beberapa faktor, yaitu:

1) Selama ini masyarakat Desa Margosari menggarap dan memanfaatkan tanah dalam kawasan hutan tanpa ada izin dari Dinas Kehutanan maupun Instansi terkait lainnya. Mereka menguasai tanah tanpa memiliki sertifikat hak atas tanah;

2) Model ini mengutamakan win-win solution. Negara mendapatkan keuntungan dengan tetap memiliki kawasan hutan, sedangkan masyarakat juga masih dapat memanfaatkan tanah yang mereka kuasai/manfaatkan sejak lama untuk kegiatan-kegiatan yang sesuai dengan fungsi hutan;

3) Program perhutanan sosial tidak terlalu membutuhkan waktu yang lama, dan tidak sulit dalam hal koordinasi antar instansi;

4) Dari segi biaya, model ini lebih meringankan pemerintah.

b. Perubahan Batas Kawasan Hutan.

Model ini dilakukan dengan terlebih dahulu melakukan penataan tata batas kawasan hutan dan dilanjutkan dengan dikeluarkannya Surat Keputusan Perubahan Batas Kawasan Hutan. Dalam pelaksanaannya, pejabat yang berwenang harus tetap memperhatikan aspek ekologis dari kawasan hutan tersebut, hal ini dilakukan demi terjaganya kelestarian hutan. Dalam pelaksanaan model ini juga harus diperhatikan aturan mengenai tidak bolehnya pelepasan kawasan hutan mengurangi luas kawasan hutan tetap, dan tetap menjamin luas kawasan hutan paling sedikit $30 \%$ dari luas daerah aliran sungai, pulau, dan/atau provinsi dengan sebaran yang proporsional. Pemilihan model ini didasarkan pada beberapa faktor, yaitu:

1) Selama ini masyarakat Desa Margosari menggarap dan memanfaatkan tanah dalam kawasan hutan tanpa ada izin dari Dinas Kehutanan maupun Instansi terkait lainnya. Mereka menguasai tanah tanpa memiliki sertifikat hak atas tanah;

2) Dengan adanya Berita Acara Tata Batas Kawasan Hutan Lindung Register 22 Way Waya Kabupaten Pringsewu yang dikeluarkan pada tahun 2014, akan lebih memudahkan, menghemat biaya, dan mempercepat dalam proses pelaksanaan penyelesaiaan melalui model ini;

3) Masyarakat tidak mengalami konflik sosial apabila mereka tetap di wilayah itu, dan kepastian hukum kepemilikan tanahnya juga lebih terjamin.

Pemberian kepastian hukum terkait kepemilikan atau penguasaan tanah yang telah berada di luar kawasan hutan karena ada perubahan batas kawasan hutan adalah dengan melakukan pensertifikatan tanah. Dinas Kehutanan dan Kantor Pertanahan Kabupaten Pringsewu menginginkan apabila memang wilayah Desa Margosari ingin untuk disertifikatkan, maka hendaknya Tata Batas dan Peta Batas Kawasan Hutan Lindung Register 22 Way Waya dapat dipertegas dengan Surat Keputusan Pelepasan Kawasan Hutan dari Menteri Lingkungan Hidup dan Kehutanan. Sepanjang sesuai dengan Peraturan Perundang-Undangan yang berlaku, dan jelas pelepasan serta batas-batasnya Kantor Pertanahan Kabupaten Pringsewu tidak dapat menolak untuk melakukan proses pensertifikatan tanah di Desa Margosari.

\section{Penutup}

1. Masyarakat Desa Margosari memanfaatkan lahan di sekitar kawasan hutan untuk berladang, usaha pertambangan skala kecil, dan bermukim. Tanah di desa Margosari yang berada di luar dan di dalam kawasan hutan tersebut belum ada yang bersertifikat. Sebagian 
besar bukti kepemilikannya adalah surat keterangan tanah, dan/atau surat peralihan di bawah tangan;

2. Model penyelesaian status hukum tanah di dalam kawasan hutan yang dikuasai masyarakat Desa Margosari adalah melalui:

a. Perhutanan sosial, yang mengutamakan penyelesaiaan secara win-win solution. Negara mendapatkan keuntungan dengan tetap memiliki kawasan hutan, sedangkan masyarakat Desa Margosari masih dapat memanfaatkan tanah yang mereka kuasai untuk kegiatankegiatan yang sesuai dengan fungsi hutan.

b. Perubahan Batas Kawasan Hutan, yang lebih menjamin kepastian hukum kepemilikan tanah masyarakat, dapat menghemat biaya, serta mudah dan cepat pelaksanaannya.

\section{DAFTAR PUSTAKA}

A. Buku

Hutagalung, Arie S. (2005). Tebaran Pemikiran Seputar Masalah Hukum Tanah. Jakarta: Lembaga Pemberdayaan Hukum Indonesia.

\section{B. Jurnal}

Fx. Sumarja, Muhammad Akib, "Forest Resources Access Moro-Moro Farmer at Register 45 Lampung", Fiat Justisia Jurnal Ilmu Hukum, Vol. 12 No.1, (2018).

Inrayanto, Oktinaldi, "Model Pengolahan Hutan Lindung Sebagai Lahan Pertanian Masyarakat (Studi Kasus di Kenagarian Air Dingin Kecamatan Lembah Gumanti Kabupaten Solok)", Skripsi, Jurusan Antropologi, Fakultas Ilmu Sosial dan politik, Sumatera Barat: Universitas Andalas, (2012).

\section{Peraturan Perundang-Undangan}

Undang-Undang Nomor 5 Tahun 1960 tentang Peraturan Dasar Pokok Agraria.

Undang-Undang Nomor 41 Tahun 1999 Tentang Kehutanan Menjadi Undang-Undang.

Peraturan Pemerintah Republik Indonesia Nomor 24 Tahun 1997 Tentang Pendaftaran Tanah.

Peraturan Pemerintah Republik Indonesia Nomor 34 Tahun 2002 Tentang Tata Hutan dan Penyusunan Rencana Pengelolaan Hutan, Pemanfaatan Hutan, dan Penggunaan Kawasan Hutan.

Peraturan Pemerintah Republik Indonesia Nomor 104 Tahun 2015 Tentang Tata Cara Perubahan Peruntukan dan Fungsi Kawasan Hutan.

Peraturan Presiden No. 88 Tahun 2017 Tentang Penyelesaiaan Penguasaan Tanah dalam Kawasan Hutan.

Keputusan Presiden Nomor 32 Tahun 1990 Tentang Pengelolaan Kawasan Lindung.

Keputusan Menteri Kehutanan Nomor: 70/Kpts-II/2001 jo. Nomor: Sk. 48/ Menhut-II/2004 Tentang Perubahan Keputusan Menteri Kehutanan Nomor 70/Kpts-II/2001 Tentang Penetapan Kawasan Hutan, Perubahan Status dan Fungsi Kawasan Hutan. 
